\title{
MODELING AND OPTIMIZATION OF TRANSESTERIFICATION OF BENISEED OIL TO BENISEED METHYLESTER: A CASE OF ARTIFICIAL NEURAL NETWORK VERSUS RESPONSE SURFACE METHODOLOGY
}

\author{
Adepoju T. F. ${ }^{\uparrow}{ }^{\uparrow}---$ Okunola A. A. ${ }^{2}$ \\ 'Chemical Engineering Department, Landmark University, Omu-Aran, Kwara State, Nigeria \\ ${ }^{2}$ Agricultural and Biosystem Engineering Department, Landmark University, Omu-Aran, Kwara State, Nigeria
}

\begin{abstract}
In this research work, statistical approach ( $A N N$ and $R S M)$ were used to optimize the transesterification of beniseed oil to beniseed methyl ester (BME). Analyses of an heterogeneous catalyst (Mangifera indica powdered) obtained from unripe Mangifera indica peels showed that the powder consist macro elements such as $\mathrm{K}$ (59.85\%), Si (30.53\%), $\mathrm{Cl}$ (4.58\%), $\mathrm{Al}$ (3.05\%) and $\mathrm{Ca}$ (1.05\%) and micro elements such as $P$ (0.196\%), S (0.593\%), Mn (0.043\%), Fe (0.037\%), Zn (0.008\%), Rb (0.042\%) and Sr (0.032\%). ANN predicted optimal condition for Beniseed methyl ester produced was $X_{s}=60.0 \mathrm{~min}, X_{2}=1.0$ wt.\%, $X_{s}=57$ ${ }^{\circ} \mathrm{C}$ and $\mathrm{X}_{*}=6.0$. The predicted BME $(94.40 \%(w / w))$ under this condition was validated to be of $93.80 \%$ $(w / w)$. Meanwhile, RSM predicted $94.20 \%$ (w/w) at the following condition $X_{t}=62.0 \mathrm{~min}, X_{2}=0.9$ wt. $\%, X_{s}=60{ }^{\circ} \mathrm{C}$ and $X_{4}=6.5$ was validated as $92.80 \%$ (w/w). The results obtained showed the superiority of ANN over RSM owing to its higher values of predicted value, RMSE, AAD, $R^{2}$ and $R^{2}{ }_{A j .}$. The fatty acid profile and the physicochemical properties of the BME indicated that, BME can serve as alternative fuel for conventional diesel.
\end{abstract}

Keywords: Optimization, Response surface methodology, Artificial neural network, Fatty acid profile, Physicochemical properties, Beniseed methyl ester.

\section{Contribution/ Originality}

This study contributes in the existing literature to the process conversion of oil to diesel. This study uses new estimation methodology in the use of heterogeneous catalyst obtained from agricultural waste. This study originates new way of using statistical software (ANN and RSM) to improve the yield of biodiesel. This study is one of very few studies which have investigated 
the use of heterogeneous catalyst to produced biodiesel. The paper contributes the first use of Mangifera indica (Mango) peels as heterogeneous base catalyst.The paper's primary contribution is finding that biodiesel can be obtained by the use of biomass waste. This study documents economic impact of using Mangifera indica (Mango) peels as heterogeneous base catalyst to produce biodiesel.

\section{INTRODUCTION}

As per the literature survey, the use of statistical software to optimize process conditions is receiving more attention day by day. Classical modeling techniques, such as response surface methodology (RSM) is an important tool which has been used extensively in laboratory research as well as industrial research, it major advantage is the capability to reduce the number of standard experimental runs, required to provide classically acceptable results [1]. In view of this, Betiku and Adepoju [2] worked on methanolysis optimization of sesame oil to biodiesel and fuel quality characterization using RSM. Jeong, et al. [3] carried out research on optimization of transesterification of animal fat ester using RSM. In the same vein, [4] worked on the biodiesel production from crude cottonseed oil using RSM. Statistical approach to the optimization of citric acid production using filamentous fungus Aspergillus niger grown on sweet potato starch hydrolyzate using RSM was carried out by Betiku and Adesina [1]. Tiwari, et al. [5] applied the same tool to optimized process of biodiesel production from jatropha oil. Statistical approach to alcoholysis optimization of sorrel (hibiscus sabdariffa) seed oil to biodiesel and emission assessment of its blends was carried out by Betiku, et al. [6]. Meanwhile, Adepoju, et al. [7] carried out worked on an innovative approach to biotransformation of benzaldehyde to L-PAC via free cells of Saccharomyces cerevisae in the presence of $\beta$-cyclodextrin using the same software. In another work, Adepoju, et al. [8] worked on optimization of benzyl alcohol production via biotransformation of benzaldehyde using free cell of saccharomyces cerevisiae in presence the $\beta$ cyclodextrin using RSM. Guan and Yao [9] also make used of RSM in optimization of viscozyme L-assisted extraction of oat bran protein.

ANN is a learning system based on a computational technique that can simulate the neurological processing ability of the human brain and can be applied to quantify a non-linear relationship between connecting factors and actual responses by means of iterative training of data obtained from a designed experiment [10]. ANNs show superiority as a modeling technique for data sets showing non-linear relationships, and thus for both data fitting and prediction abilities $[10,11]$. It has been use to solve myriads of problems in the field of medicine, metrology, neurology, biology, phycology, science, mathematics and engineering [12]. Ghaffari, et al. [13] worked on performance comparism of neural network training algorithms in modeling of biomodal drug delivery, Gueguim Kana, et al. [14] optimized biogas production from sawdust using ANN whereas Rajendra, et al. [15] applied the same tool to optimized the pretreatment 
process parameters for biodiesel production, Ebrahimpour, et al. [16] also apply ANN in optimization studies of lipase production while Adepoju and Olawale [17] optimize transesterification of chrysophyllum albidium seed oil to chrysophyllum albidium oil biodiesel using artificial neural network. However, Betiku and Ajala [18] compared the performance of ANN and RSM in modeling and optimization of thevetia peruviana (yellow oleander) oil biodiesel synthesis via musa paradisiacal (plantain) peels, it was reported that ANN offers a promising outlook in the estimation of the optimum variables for biodiesel production, Adepoju, et al. [19] also compared the performance of ANN and RSM for achieving desire benzene alcohol in the biotransformation of benzaldehyde using free cells of Saccharomyces cerevisae and the effect of $\beta$-cyclodextrin and reported that ANN methodology presents a better alternative than the RSM model meanwhile, Dasai, et al. [20] compared the tools to work on fermentative production of scleroglucan, and established that using RSM and ANN along together showed a clear superiority over using each of them alone, Bosco Kana, et al. [21] compared ANN and RSM in modeling and optimization of citric acid production by AspergillusnigerMCBN297 and reported that RSM provided good insight on parameters interaction.In this study, an effort was made to optimize the reaction variables (reaction time, reaction temperature, heterogeneous catalyst amount and methanol / oil molar ratio) for transesterification of Sesamum indicum oil biodiesel synthesis via Mangifera indica (Mango) peels as heterogeneous base catalyst while comparing the performance of ANN and RSM.

\section{MATERIALS AND METHODS}

\subsection{Materials}

The seeds of Sesamum indicum were collected from Kabba, Nigeria. The dirty seeds were washed to remove the adherent dirty, sun dried for six days and then winnowed to remove the foreign matter (i.e. chaffs and grit). The cleaned seeds were then grinded into powdery using grinding machine. The $M$. indica (unripe) used in this study was obtained from Landmark University farm, Omu Aran. All chemical and reagents used were of analytical grades made by GFS Chemicals, Inc., 867 McKinley Ave., Columbus OH 43223 (99.7-100\%) and BDH Analar Ltd., Poole England (99\%) and supplied by FINLAB Nig. Ltd.

\subsection{Methods}

\subsubsection{Beniseed (Sesamum Indicum) Oil Extraction}

A $250 \mathrm{ml}$ Soxhlet extractor apparatus with n-hexane as a solvent was used for oil extraction. At first, the thimble of apparatus was charged with a known weight of the powder seed placed in a muslin cloth. The solvent containing part of the apparatus was filled with a known volume of nhexane, fixed to the end of the thimble, and a condenser was tightly fixed at the bottom end of the extractor. The whole set up was placed in a temperature controlled heating mantle and heatedup 
at temperature of $68-70{ }^{\circ} \mathrm{C}$. Excess solvent in the extracted oil was recycled and recovered by distillation. The oil obtained was stored in a five (5) litre keg for biodiesel production (methyl ester).

\subsubsection{Preparation of Mangifera Indica Peels Catalyst}

Unripe Mangifera indica fruit was carefully peeled and the peels were washed with ionized water, oven dried at $70{ }^{\circ} \mathrm{C}$ for $38 \mathrm{~h}$ until the constant weight was achieved. The dried peels were milled into powder and then sieved to obtain the fine powder. The fine powdered was placed in a crucible and heated to a temperature of $350{ }^{\circ} \mathrm{C}$ in a furnace for $4 \mathrm{~h}$ to achieved proper dryness. The dried Mangifera indica powdered was packed into a cleaned covered plastic bottle for further use as catalyst.

\subsubsection{Characterization of Mangifera Indica Powdered}

The elemental contents of the Mangifera indica powdered was determined by using Atomic Absorption Spectrometry (AAS) for Magnesium, Flame photometer for Sodium and XRF spectrometry for other elements (aluminum, silicon, phosphorous, chlorine, potassium, calcium, zinc, iron, copper, chromium, manganese, nickel etc.).

\subsubsection{Transesterification of Beniseedoil to Beniseed Methylester (BME)}

One Liter glass reactor was charged with a known weight of the preheated Beniseed oil on a hot plate magnetic stirrer, a known amount of Mangifera indica powdered acting as catalyst was dissolved in a specific volume of methanol in a separate $500 \mathrm{ml}$ reactor flask, stirrer rigorously, and then transferred into the preheated oil placed on the hot plate magnetic stirrer. The content of reactor was heated up to a known temperature until the reaction reaches completion at a required time. The content of the reactor was transferred into a $250 \mathrm{ml}$ separating funnel, and allowed to separate within $12 \mathrm{~h}$. Two layers was clearly noted, the lower layer which contained glycerol was tapped off from the bottom funnel, and the upper layer which contained biodiesel was washed with ionized water to removed untapped glycerol, residual catalyst and methanol present. The clearly washed light yellowish biodiesel was dried over calcium chloride powder to absorb the unwanted water, and then filtered to remove the deliquescence calcium chloride. The dried, light yellowish, low viscous BME was calculated using (Eq. (1)).

$$
B M E=\frac{\text { weight of produced biodiesel }}{\text { weight of the preheated oil used }}
$$

\subsubsection{Experimental Design for Transesterication and Statistical Analysis by RSM}

To test the effects of reaction variables (reaction time, temperature of reaction, catalyst amount and methanol / oil molar ratio) RSM was employed. A central composite rotatable design 
(CCRD) with four - factor - five - levels, which generate 30 experimental runs including factorial points, center points and axial points, was used for fitting a second order-four-variables response surface. Table 1 gives the factors and their levels while the 30 - CCRD experimental runs generated are presented in Table 2. The experiment was randomized to minimize the effects unexpected variability in the experimental responses. The simple linear regression model equation showing the functional relationship between the methylester yield and the independent variables is a linear function plus and error term is presented in (Eq. (2)).

$$
\begin{gathered}
Y=\alpha_{o}+\alpha_{1} X_{1}+\alpha_{2} X_{2}+\alpha_{3} X_{3}+\alpha_{4} X_{4}+\alpha_{12} X_{1} X_{2}+\alpha_{13} X_{1} X_{3}+\alpha_{14} X_{1} X_{4}+\alpha_{23} X_{2} X_{3} \\
+\alpha_{24} X_{2} X_{4}+\alpha_{34} X_{3} X_{4}+\alpha_{11} X_{1}^{2}+\alpha_{22} X_{2}^{2}+\alpha_{33} X_{3}^{2}+\alpha_{44} X_{4}^{2}+\epsilon
\end{gathered}
$$

$Y$ is the value of response corresponding (biodiesel yield) to the value of $X_{1}, X_{2}, X_{3}, X_{4}$ of the explanatory variable, $\alpha_{0}$ is the intercept, $\alpha_{1}, \alpha_{2}, \alpha_{3}$ and $\alpha_{4}$ are the linear coefficients, $\alpha_{12}, \alpha_{13}, \alpha_{14}, \alpha_{23}, \alpha_{24}$ and $\alpha_{34}$ are interaction coefficients, while $\alpha_{11}, \alpha_{22}, \alpha_{33}$ and $\alpha_{44}$ are the quadratic coefficients. $\varepsilon$ is the error term. For the regression analysis of the experimental data, design expert 9/DX9. Exe.Software was used.The results obtained were also analyzed using statistical model equations (Eq (3), Eq. (4) and Eq. (5)).

$$
\begin{aligned}
& R^{2}=1-\sum_{i=1}^{n} \frac{\left(X_{i, \text { cal }}-X_{i, \exp }\right)^{2}}{\left(X_{\text {avg } \text { exp }}-X_{i, \text { exp }}\right)^{2}} \\
& A D D=\left\{\frac{1}{n}\left[\sum_{i=1}^{n}\left(\frac{X_{i, \text { exp }}-X_{i, \text { cal }}}{X_{i, \exp }}\right)\right]\right\} \\
& R M S E=\sqrt{\frac{\sum\left(X_{i, c a l}-X_{i, \text { exp }}\right)}{n}}
\end{aligned}
$$

Where $n$ is the number of data set, $X_{i, c a l}$ is the calculated values, $X_{i, \exp }$ is the experimental values and $X_{\text {avg,exp }}$ is the average experimental values.

Table-1.Factors and their levels for composite central rotatable design

\begin{tabular}{l|l|l|l|l|l|l}
\hline Variable & $\begin{array}{l}\text { Symbo } \\
1\end{array}$ & \multicolumn{7}{l}{ Coded factor levels } \\
\hline & & -2 & -1 & 0 & 1 & 2 \\
\hline Reaction time (min) $(\mathrm{RT})$ & $\mathrm{X}_{1}$ & 40 & 45 & 50 & 55 & 60 \\
\hline Heterogeneous catalyst amount (wt \%) (HCA) & $\mathrm{X}_{2}$ & 0.5 & 0.6 & 0.7 & 0.8 & 0.9 \\
\hline Temperature of reaction $\left({ }^{\circ} \mathrm{C}\right)(\mathrm{TR})$ & $\mathrm{X}_{3}$ & 40 & 45 & 50 & 55 & 60 \\
\hline Methanol / oil molar ratio (M/OMR) & $\mathrm{X}_{4}$ & 3 & 4 & 5 & 6 & 7 \\
\hline
\end{tabular}

\subsection{Modeling and Optimization Studies by ANN and RSM}

In this study, a 2.5 CPC-X Software Neural Power new version was used. Multilayer Normal Feed Forward (MNFF) and Multilayer Full Feed Forward (MFFF) networks were used for predictive accuracy of oil and biodiesel yields. Search approach used was force approach. The two networks were trained by the Quick Prop (QP) learning algorithms and default stopping of 120,000 iterations. For the input layer, a total of four (4) layer numbers was used and the node number of input layer was four (4). For the output layer, Node Number was one (1), the transfer function was Tanh and the slope of transfer function and the hidden Layer was also one (1). 
Meanwhile, the node number of output layer was twelve (12) with Tanh transfer function. The slope of transfer function was also one (Fig. 1). Similarly for RSM, the CCD data was dividedinto training and testing data sets. Twenty four (24) out of the thirty experimental obtained data were used as the training set while six (6) were used for the testing set. The test of significance,

Table-2.Central Composite Design (CCD), Experimental, Predicted and Residual Values for Five - Level-Four Factors

Response Surface Analysis

\begin{tabular}{|c|c|c|c|c|c|c|c|c|c|}
\hline Run & $\begin{array}{l}\text { RT } \\
(\min )\end{array}$ & $\begin{array}{l}\text { HCA } \\
\text { (wt. \%) }\end{array}$ & $\begin{array}{l}\text { TR } \\
\left({ }^{\circ} \mathbf{C}\right)\end{array}$ & $\begin{array}{l}\mathrm{M} / \\
\mathrm{OM} \\
\mathbf{R}\end{array}$ & $\begin{array}{l}\text { EY(BME) } \\
\%(w / w)\end{array}$ & $\begin{array}{l}\text { Predicted } \\
\text { value RSM }\end{array}$ & $\begin{array}{l}\text { Residual } \\
\text { RSM }\end{array}$ & $\begin{array}{l}\text { Predicted } \\
\text { value } \\
\text { ANN }\end{array}$ & $\begin{array}{l}\text { Residual } \\
\text { ANN }\end{array}$ \\
\hline 1 & 45 & 0.6 & 45 & 4 & 83.00 & 82.49 & 0.51 & 83.577 & 0.57704 \\
\hline 2 & 55 & 0.6 & 45 & 4 & 85.70 & 86.53 & -0.83 & 85.153 & 0.54714 \\
\hline 3 & 45 & 0.8 & 45 & 4 & 88.56 & 88.40 & 0.16 & 87.724 & 0.83622 \\
\hline 4 & 55 & 0.8 & 45 & 4 & 87.55 & 87.74 & -0.19 & 88.325 & 0.77495 \\
\hline 5 & 45 & 0.6 & 55 & 4 & 94.78 & 94.78 & 0.000 & 95.521 & 0.74070 \\
\hline 6 & 55 & 0.6 & 55 & 4 & 67.60 & 68.15 & -0.55 & 67.813 & 0.21272 \\
\hline 7 & 45 & 0.8 & 55 & 4 & 92.27 & 92.20 & 0.069 & 92.155 & 0.11506 \\
\hline 8 & 55 & 0.8 & 55 & 4 & 84.40 & 84.17 & 0.23 & 84.457 & 0.05665 \\
\hline 9 & 45 & 0.6 & 45 & 6 & 94.78 & 94.78 & 0.000 & 95.134 & 0.35393 \\
\hline 10 & 55 & 0.6 & 45 & 6 & 88.62 & 87.88 & 0.74 & 88.422 & 0.19777 \\
\hline 11 & 45 & 0.8 & 45 & 6 & 71.10 & 71.00 & 0.10 & 70.996 & 0.10408 \\
\hline 12 & 55 & 0.8 & 45 & 6 & 90.10 & 90.54 & -0.44 & 90.304 & 0.20392 \\
\hline 13 & 45 & 0.6 & 55 & 6 & 81.50 & 81.64 & -0.14 & 81.409 & 0.09138 \\
\hline 14 & 55 & 0.6 & 55 & 6 & 96.20 & 96.68 & -0.48 & 95.406 & 0.79387 \\
\hline 15 & 45 & 0.8 & 55 & 6 & 60.86 & 61.01 & -0.15 & 60.898 & 0.03839 \\
\hline 16 & 55 & 0.8 & 55 & 6 & 86.35 & 86.45 & -0.10 & 86.44 & 0.09047 \\
\hline 17 & 40 & 0.7 & 50 & 5 & 84.42 & 84.81 & -0.39 & 84.504 & 0.08435 \\
\hline 18 & 60 & 0.7 & 50 & 5 & 92.78 & 92.40 & 0.38 & 93.776 & 0.99637 \\
\hline 19 & 50 & 0.5 & 50 & 5 & 94.78 & 94.78 & 0.000 & 94.463 & 0.31722 \\
\hline 20 & 50 & 0.9 & 50 & 5 & 90.80 & 91.08 & -0.28 & 91.127 & 0.32732 \\
\hline 21 & 50 & 0.7 & 40 & 5 & 69.13 & 69.32 & -0.19 & 69.133 & 0.00291 \\
\hline 22 & 50 & 0.7 & 60 & 5 & 94.78 & 94.78 & 0.000 & 94.846 & 0.06647 \\
\hline 23 & 50 & 0.7 & 50 & 3 & 93.30 & 92.08 & 1.22 & 92.619 & 0.68139 \\
\hline 24 & 50 & 0.7 & 50 & 7 & 91.49 & 90.95 & 0.54 & 91.573 & 0.08283 \\
\hline 25 & 50 & 0.7 & 50 & 5 & 70.50 & 70.03 & 0.47 & 88.903 & 18.4030 \\
\hline 26 & 50 & 0.7 & 50 & 5 & 94.78 & 94.78 & 0.000 & 88.903 & 5.8772 \\
\hline 27 & 50 & 0.7 & 50 & 5 & 94.78 & 94.78 & 0.000 & 88.903 & 5.8772 \\
\hline 28 & 50 & 0.7 & 50 & 5 & 96.62 & 96.94 & -0.32 & 88.903 & 7.7172 \\
\hline 29 & 50 & 0.7 & 50 & 5 & 81.70 & 81.38 & 0.32 & 88.903 & 7.2028 \\
\hline 30 & 50 & 0.7 & 50 & 5 & 95.59 & 96.27 & -0.68 & 88.903 & 6.6872 \\
\hline
\end{tabular}

ANOVA test and regression equation were used to achieve the modeling and optimization involved in BME production.

\subsection{Analysis of Qualities of BME and There Free Fatty Acid Compositions}

The qualities such as refractive index, moisture content, viscosity at $40{ }^{\circ} \mathrm{C}$, acid value, saponification value, peroxide value, specific gravity, \% FFA, cetane number etc. of BMEwas carried out by AOAC [22] methods, the mean molecular mass was obtained by the method of Akintayo and Bayer [23], the higher heating value was determined by Demirbas [24] method, 
iodine value was obtained by Wijs method. The pour point and cloud point of the methylesterwere determined by the standard ASTM D2500 method. Free fatty acid of methylester was determined using gas chromatography (GC) (HP 6890 powered with HP Chem Station Rev. A 09.01 [ 1206] Software). $50 \mathrm{mg}$ methylester was esterified for five minute at $95^{\circ} \mathrm{C}$ with $3.4 \mathrm{ml}$ of the $0.5 \mathrm{M} \mathrm{KOH}$ in dry methanol. The mixture was neutralized using by adding 0.7 $\mathrm{M} \mathrm{HCl}$ and $3 \mathrm{ml}$ of $14 \%$ boron triflouride in methanol. The whole mixture was heated for $5 \mathrm{~min}$ at the temperature of $90{ }^{\circ} \mathrm{C}$ to achieve complete methylation process. The fatty acids were thrice extracted from the mixture with redistilled n-hexane. The content was concentrated to $1 \mu \mathrm{l}$ for gas chromatography analysis with $1 \mu \mathrm{l}$ was injected into the injection port of GC.

\section{RESULTS AND DISCUSSION}

\subsection{Elemental Analysis of Mangifera Indica Powdered Catalyst}

The results of elemental analysis of Mangifera indica powdered used as heterogeneous catalyst were presented in Table 3. Analyses showed that the Mangifera indica powdered consist of macro as well as micro elements. The macro elements were found to be K (59.85\%), Si (30.53 $\%), \mathrm{Cl}(4.58 \%), \mathrm{Al}(3.05 \%)$ and $\mathrm{Ca}(1.05 \%)$. The major micro elements are $\mathrm{P}(0.196 \%), \mathrm{S}(0.593$ \%), Mn (0.043 \%), Fe (0.037 \%), Zn (0.008\%), Rb (0.042\%) and Sr (0.032 \%). The catalytic activity of the Mangifera indica powdered can be traced to high proportion of macro elements and the problem of leaching of other metallic constituents such as $\mathrm{Na}$ and $\mathrm{Ca}$ into the biodiesel product was not observed as a result of low levels of these metals in the powder [18].

Table-3.Elemental analysis of Mangifera indica peels powdered

\begin{tabular}{l|l|r|l}
\hline $\mathbf{S} / \mathbf{N}$ & Elemental symbols & Concentration $(\mathbf{g} / \mathbf{l})$ & Percentage mass fraction $\%$ \\
\hline 1 & $\mathrm{Al}$ & $12,543.6$ & 3.04732567 \\
\hline 2 & $\mathrm{Si}$ & $125,643.4$ & 30.52364219 \\
\hline 3 & $\mathrm{P}$ & 806.4 & 0.19590575 \\
\hline 4 & $\mathrm{~S}$ & 2440.1 & 0.59279468 \\
\hline 5 & $\mathrm{Cl}$ & $246,342.6$ & 4.58478742 \\
\hline 6 & $\mathrm{~K}$ & 4312.7 & 59.84614693 \\
\hline 7 & $\mathrm{Ca}$ & 176.6 & 1.04772166 \\
\hline 8 & $\mathrm{Mn}$ & 152.2 & 0.04290297 \\
\hline 9 & $\mathrm{Fe}$ & 32.4 & 0.03697526 \\
\hline 10 & $\mathrm{Zn}$ & 172.3 & 0.00787121 \\
\hline 11 & $\mathrm{Rb}$ & 132.0 & 0.04185834 \\
\hline 12 & $\mathrm{Sr}$ & $411,626.5$ & 0.03206791 \\
\hline $\mathrm{SUM}$ & & & 100 \\
\hline
\end{tabular}

\subsection{Modeling and Optimization of Transesterification Reaction by RSM}

The results of the transesterification reaction using CCRD experimental design was presented in Table 2 above. Fig 1 showed the plot of predicted against the experimental biodiesel yield. Based on the constraints and the single objective function in (Eq. (2)), the model equation 
that correlate the controllable variables and the single objective function (response BME) is given in Eq. ((6)).

$$
\begin{aligned}
B M E \% /=94.78 & +2.22 x_{1}+3.87 x_{2}+2.56 x_{3}+6.32 x_{4}-1.25 x_{1} x_{2}+1.05 x_{1} x_{3}-2.09 x_{1} x_{4} \\
- & 1.37 x_{2} x_{3}-4.25 x_{2} x_{4}-0.70 x_{3} x_{4}-2.17 x_{1}^{2}-4.43 x_{2}^{2}-0.80 x_{3}^{2} \\
- & 2.79 x_{4}^{2}
\end{aligned}
$$

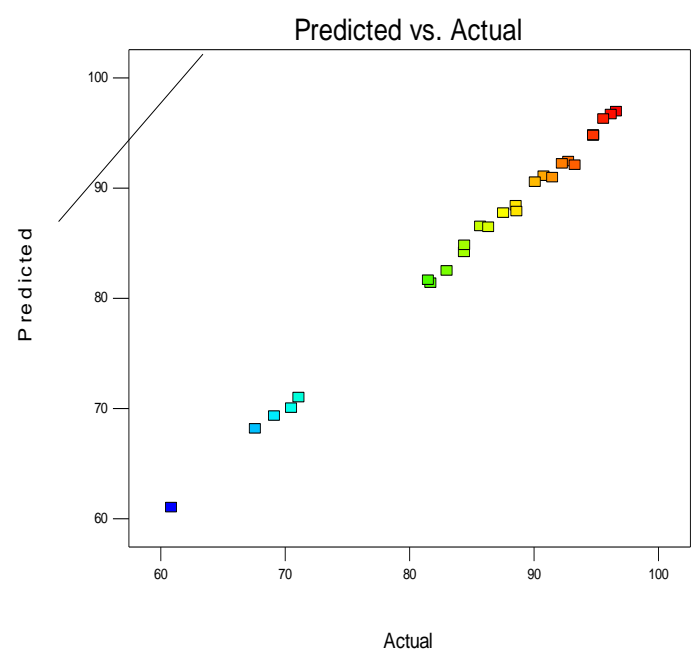

RSM

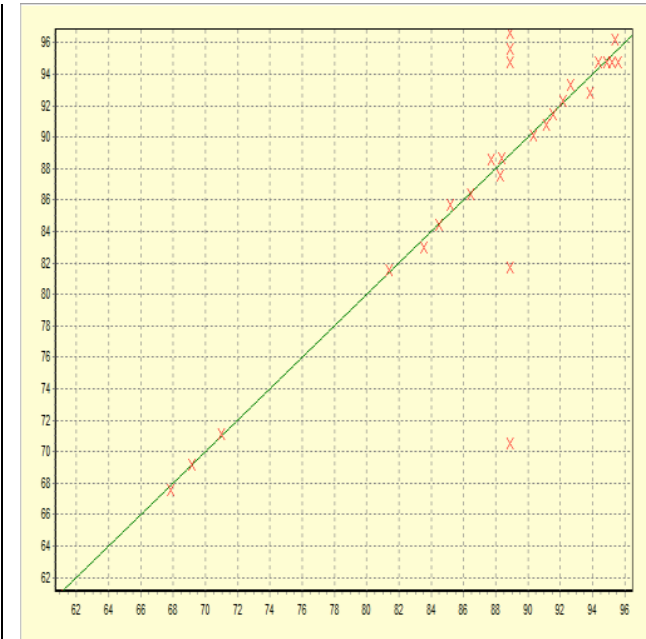

ANN

Fig-1.Graph of predicted against the Actual yield for RSM and ANN

ANOVA test, test of significant, coefficient of determination $\left(\mathrm{R}^{2}\right)$ and $R_{A d j}^{2}$. were used to evaluate the statistical significant of the model equation. The results of test of significant test were presented in Table 4. Observation on the results showed that all the variables are remarkable significant at $95 \% \mathrm{CI}$ level $(\mathrm{p}<0.05)$. However, the variable $\mathrm{X}_{4}$ with $F$-test value $=$ 2621.12, $\mathrm{p}<0.0001$, is the most significant variable. The results of ANOVA and analysis of variance were presented in Table 5. Observation showed that all the factors has negative coefficient of estimation effects on the response except $\mathrm{X}_{1}, \mathrm{X}_{2}, \mathrm{X}_{3}, \mathrm{X}_{4}$ and $\mathrm{X}_{1} \mathrm{X}_{3}$, respectively with positive impact.

All the degree of fredom (df) associated with sum of the squares in Table 5 are unity (1), the standard error are all lesser than one, and the variance inflation factor ranged from 1.00 to 1.05 implied a high significance for the regression model [25]. The coefficient of determination $\left(\mathrm{R}^{2}\right)$ and $R_{A d j}^{2}$. were evaluated as $98.85 \%$ and $99.62 \%$, respectively.

Table-4.Test of Significance for Every Regression Coefficient of CCRD

\begin{tabular}{l|l|l|l|l|l}
\hline Source & Sum of Squares & df & Mean Square & F-Value & p-value \\
\hline $\mathrm{X}_{1}$ & 118.77 & 1 & 118.77 & 324.88 & $<0.0001$ \\
\hline $\mathrm{X}_{2}$ & 359.99 & 1 & 359.99 & 984.69 & $<0.0001$ \\
\hline $\mathrm{X}_{3}$ & 156.72 & 1 & 156.72 & 428.69 & $<0.0001$ \\
\hline $\mathrm{X}_{4}$ & 958.24 & 1 & 958.24 & 2621.12 & $<0.0001$ \\
\hline $\mathrm{X}_{1} \mathrm{X}_{2}$ & 24.88 & 1 & 24.88 & 68.04 & $<0.0001$ \\
\hline
\end{tabular}


International Journal of Chemical and Process Engineering Research, 2015, 2(3): 30-43

\begin{tabular}{l|l|l|l|l|l}
\hline $\mathrm{X}_{1} \mathrm{X}_{3}$ & 17.62 & 1 & 17.62 & 48.19 & $<0.0001$ \\
\hline $\mathrm{X}_{1} \mathrm{X}_{4}$ & 69.93 & 1 & 69.93 & 191.29 & $<0.0001$ \\
\hline $\mathrm{X}_{2} \mathrm{X}_{3}$ & 29.89 & 1 & 29.89 & 81.77 & $<0.0001$ \\
\hline $\mathrm{X}_{2} \mathrm{X}_{4}$ & 289.60 & 1 & 289.60 & 792.14 & $<0.0001$ \\
\hline $\mathrm{X}_{3} \mathrm{X}_{4}$ & 7.85 & 1 & 7.85 & 21.48 & 0.0003 \\
\hline $\mathrm{X}_{1}{ }^{2}$ & 129.44 & 1 & 129.44 & 354.07 & $<0.0001$ \\
\hline $\mathrm{X}_{2}{ }^{2}$ & 537.95 & 1 & 537.95 & 1471.49 & $<0.0001$ \\
\hline $\mathrm{X}_{3}{ }^{2}$ & 17.71 & 1 & 17.71 & 48.46 & $<0.0001$ \\
\hline $\mathrm{X}_{4}{ }^{2}$ & 212.92 & 1 & 212.92 & 582.40 & $<0.0001$ \\
\hline
\end{tabular}

Table-5.ANOVA for Response Surface Quadratic Model for Intercept.

\begin{tabular}{|c|c|c|c|c|c|c|}
\hline Factors & $\begin{array}{l}\text { Coefficient } \\
\text { Estimate }\end{array}$ & df & $\begin{array}{l}\text { Standard } \\
\text { Error }\end{array}$ & $\begin{array}{l}95 \% \mathrm{CI} \\
\text { Low }\end{array}$ & $\begin{array}{l}95 \% \text { CI } \\
\text { High }\end{array}$ & VIF \\
\hline Intercept & 94.78 & 1 & 0.25 & 94.25 & 95.31 & - \\
\hline $\mathrm{X}_{1}$ & 2.22 & 1 & 0.12 & 1.96 & 2.49 & 1.00 \\
\hline $\mathrm{X}_{2}$ & 3.87 & 1 & 0.12 & 3.61 & 4.14 & 1.00 \\
\hline $\mathrm{X}_{3}$ & 2.56 & 1 & 0.12 & 2.29 & 2.82 & 1.00 \\
\hline $\mathrm{X}_{4}$ & 6.32 & 1 & 0.12 & 6.06 & 6.58 & 1.00 \\
\hline $\mathrm{X}_{1} \mathrm{X}_{2}$ & -1.25 & 1 & 0.15 & -1.57 & -0.92 & 1.00 \\
\hline $\mathrm{X}_{1} \mathrm{X}_{3}$ & 1.05 & 1 & 0.15 & 0.73 & 1.37 & 1.00 \\
\hline $\mathrm{X}_{1} \mathrm{X}_{4}$ & -2.09 & 1 & 0.15 & -2.41 & -1.77 & 1.00 \\
\hline $\mathrm{X}_{2} \mathrm{X}_{3}$ & -1.37 & 1 & 0.15 & -1.69 & -1.04 & 1.00 \\
\hline $\mathrm{X}_{2} \mathrm{X}_{4}$ & -4.25 & 1 & 0.15 & -4.58 & -3.93 & 1.00 \\
\hline $\mathrm{X}_{3} \mathrm{X}_{4}$ & -0.70 & 1 & 0.15 & -1.02 & -0.38 & 1.00 \\
\hline $\mathrm{X}_{1}{ }^{2}$ & -2.17 & 1 & 0.12 & -2.42 & -1.93 & 1.05 \\
\hline $\mathrm{X}_{2}{ }^{2}$ & -4.43 & 1 & 0.12 & -4.67 & -4.18 & 1.05 \\
\hline $\mathrm{X}_{3}{ }^{2}$ & -0.80 & 1 & 0.12 & -1.05 & -0.56 & 1.05 \\
\hline $\mathrm{X}_{4}{ }^{2}$ & -2.79 & 1 & 0.12 & -3.03 & -2.54 & 1.05 \\
\hline \multicolumn{7}{|c|}{ Analysis of Variance of Regression Equation } \\
\hline Source & Sum of squares & df & Mean Square & F-value & p-value & \\
\hline Model & 2748.86 & 14 & 196.35 & 537.08 & $<0.0001$ & \\
\hline Residual & 5.48 & 15 & 0.37 & & & \\
\hline Lack of Fit & 5.48 & 10 & 0.55 & & & \\
\hline Pure Error & 0.000 & 5 & 0.000 & & & \\
\hline Cor Total & 2754.34 & 29 & & & & \\
\hline Variance & & & & & & 1.858 \\
\hline Standard deviation & & & & & & 1.363 \\
\hline
\end{tabular}

The variance activity that varies from a norm was determined to be 1.858 , while the square root of the variance called the standard deviation was obtained to be 1.363 .

Fig. 2, showed the 3-D graphical representation of response. The curvature nature of the graphs proved that there are perfect interactions among the controllable variables $\left(\mathrm{X}_{1}, \mathrm{X}_{2}, \mathrm{X}_{3}\right.$ and $\mathrm{X}_{4}$ ). To establish the optima condition, Forty two (42) variables combination were generated, the optimal 
International Journal of Chemical and Process Engineering Research, 2015, 2(3): 30-43
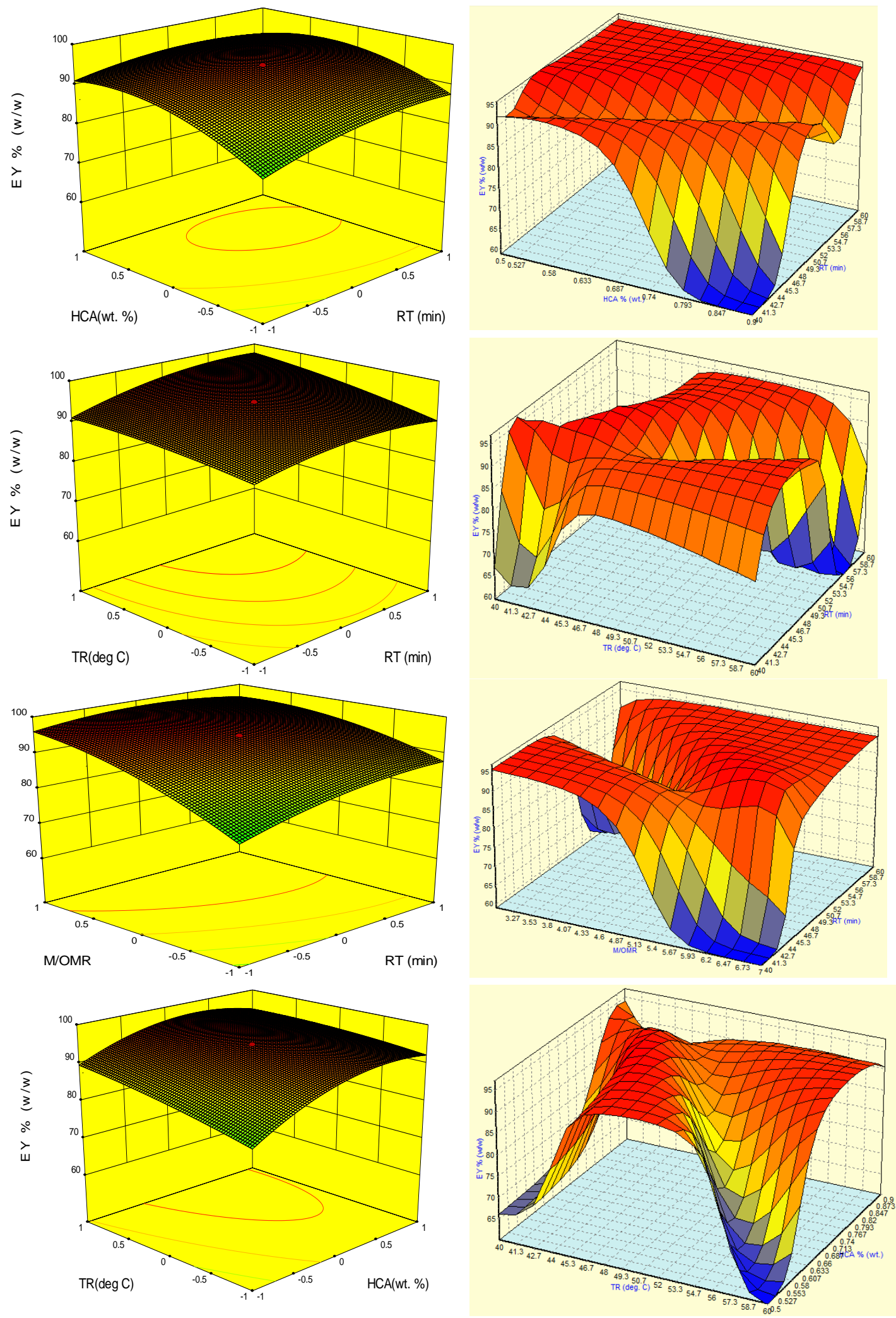

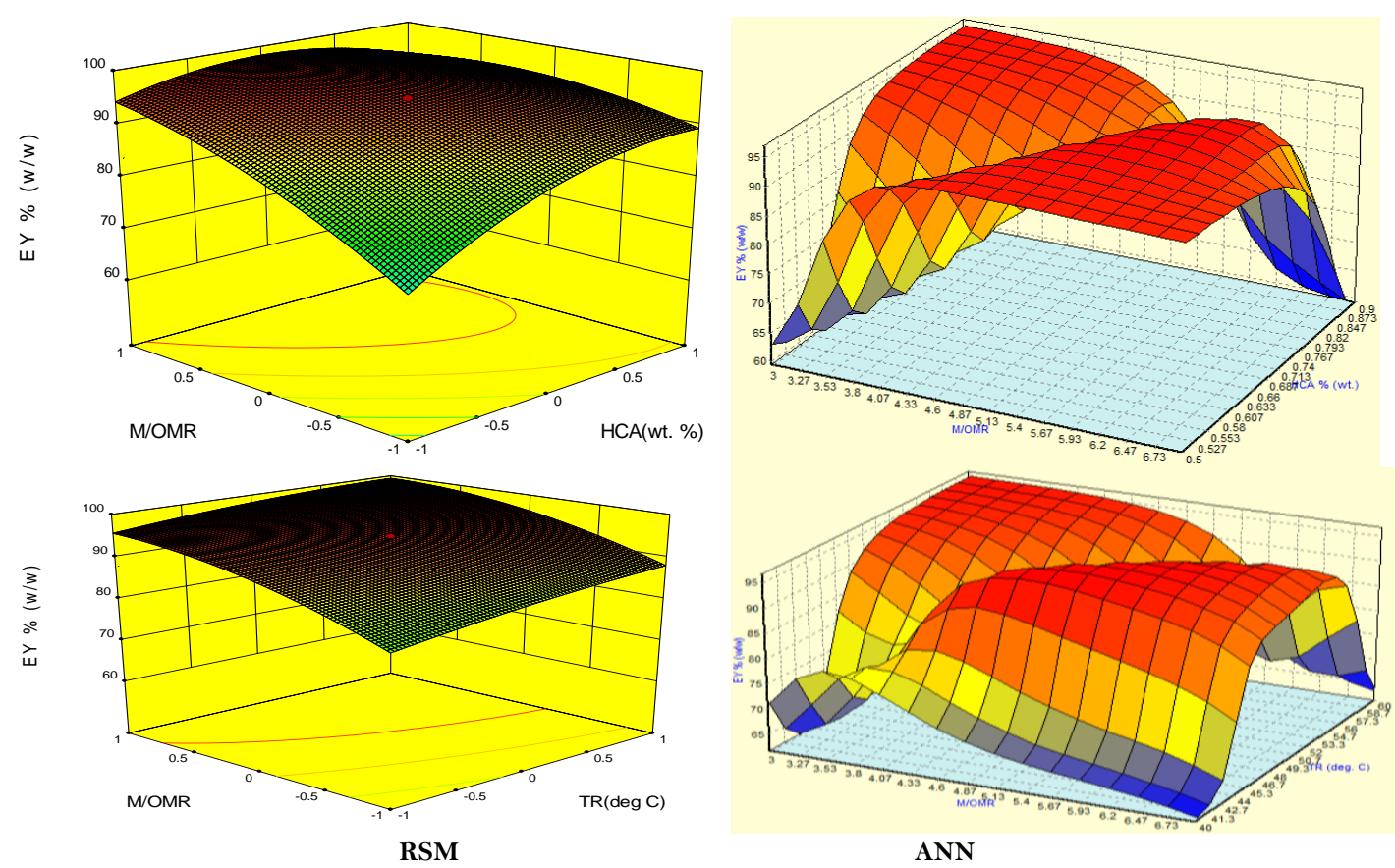

Fig-2.3. Dimensional plots RSM and ANN

Variables condition for this process was established at thirty one (31) variable combinations. This was obtained by minimizing the controllable variables while maximizing the response variable (BY). The condition was established at $\mathrm{X}_{1}=62.0 \mathrm{~min}, \mathrm{X}_{2}=0.9 \mathrm{wt} \%, \mathrm{X}_{3}=60^{\circ} \mathrm{C}$ and $\mathrm{X}_{4}=$ 6.5. The predicted BME under this condition was $94.20 \%(\mathrm{w} / \mathrm{w})$. Using these optimal condition values for three independent replicates, a mean of $92.80 \%(w / w)$ BME was achieved, which was within the range predicted by the model.

\subsection{Modeling and Optimization of Transesterification Reaction by ANN}

The experimentalresults, the predicted and the residual values were presented in Table 2 above. However, Fig. 1 above, showed the graph of predicted against the experimental yield. Based on the force approach, the connection value of N3L1-N3L2 [3.9554], with the lower [2.9554] and upper value [4.9554] proved suitable for determination of the root mean square error (RMSE) as well as average coefficient of determination $\left(\mathrm{R}^{2}\right)$ and $R_{A d j}^{2}$. The RMSE, $\mathrm{R}^{2}$ and $R_{A d j .}^{2}$ were evaluated to be $0.05100,99.999 \%$ and $99.997 \%$, respectively. The variance activity that varies from a norm was determined as 53.8600 , while the square root of the variance called the standard deviation was obtained to be 7.33894 .

Depict also in Fig. 2 above is the 3 - dimensional graphical representation by ANN software. The nature of the graphs indicated that there are outstanding mutual interactions among the variables. To establish the optima condition, forty seven (47) variables combination were generated, the optimal variables condition for this process was established at thirty three (33) variables combination. This was obtained by minimizing the controllable variables while 
maximizing the response variable $(\mathrm{BME})$. The condition was established at $\mathrm{X}_{1}=60.0 \mathrm{~min}, \mathrm{X}_{2}=$ 1.0 wt. $\%, \mathrm{X}_{3}=57^{\circ} \mathrm{C}$ and $\mathrm{X}_{4}=6.0$. The predicted BME under this condition was $94.40 \%(\mathrm{w} / \mathrm{w})$. Using these optimal condition values for three independent replicates, a mean of $93.80 \%(\mathrm{w} / \mathrm{w})$ BME was achieved, which was well within the range predicted by the model.

\subsection{ANN and RSM Performance Comparison of Beniseed Methylester (BME)}

The accuracy of models (ANN and RSM) was checked by comparing the graph of the predicted and the actual BME. Meanwhile, AAD, RMSE, $\mathrm{R}^{2}$ and $R_{A d j}^{2}$. variance and standard deviation were also evaluated to show the superiority of one model over the other. The graph of the predicted against the actual value showed by ANN indicted that nearly all of the predicted value are well within the actual value. The evaluated results of $\mathrm{AAD}, \mathrm{RMSE}, \mathrm{R}^{2}$ and $R_{\text {Adj }}^{2}$. variance and standard deviation revealed that the ANN and RSM are good optimization tools with accurate predictions (Table 5). Nevertheless, the results displayed the supremacy of ANN over RSM for the reason that predicted values $\left(93.60 \% \mathrm{w} / \mathrm{w}\right.$ for ANN; $92.80 \% \mathrm{w} / \mathrm{w}$ for RSM), $\mathrm{R}^{2}$ (99.999\% for ANN; $99.44 \%$ for RSM) and $R_{A d j .}^{2} .99 .997 \%$ for ANN; $98.72 \%$ for RSM). It can be therefore concluded that artificial neural network proved to be better in terms of modeling and optimization of transesterification of Beniseed oil to BME.

Table-6.Comparism of ANN with RSM

\begin{tabular}{l|l|l}
\hline \multirow{2}{*}{ Data } & Values & ANN \\
\cline { 2 - 3 } & RSM & 0.1820 \\
\hline AAD & 0.2100 & 0.005196 \\
\hline RMSE & 0.04567 & 0.99999 \\
\hline $\mathrm{R}^{2}$ & 0.9944 & 0.99997 \\
\hline Adjusted R ${ }^{2}$ & 0.9872 & 53.8600 \\
\hline Variance & 1.3630 & 7.33894 \\
\hline Standard deviation & 1.2767 & 93.60 \\
\hline Predicted BME \%(w/w) & 92.80 & \\
\hline
\end{tabular}

\section{CONCLUSION}

This study demonstrated that Beniseed oil can be easily transesterified to Beniseed methyl ester using a heterogeneous base catalyst. The transesterification process was effectively optimized by statistical software (ANN and RSM). The study displayed that ANN perform better than RSM due to comparison of predicted value, RMSE, AAD, $\mathrm{R}^{2}, \mathrm{R}^{2} \mathrm{Adj}$. In the meantime, the fatty acid profile and the physicochemical properties of the BME proved that, BME can serve as alternative fuel for conventional diesel.

\section{ACKNOWLEDGEMENTS}

The effort of Engr. Adesina Olusola, the staff of Landmark University, Omu-Aran, Kwara State, Nigeria, is deeply appreciated. 


\section{REFERENCES}

[1] E. Betiku and O. A. Adesina, "Statistical approach to the optimization of citric acid production using filamentous fungus aspergillus niger grown on sweet potato starch hydrolyzate using RSM," Biomass and Bioenergy, vol. 2, pp. 1-5, 2013.

[2] E. Betiku and T. F. Adepoju, "Methanolysis optimization of sesame (Sesamumindicum) oil to biodiesel and fuel quality characterization," International Journal of Energy and Environmental Engineering (IJEEE), vol. 4, pp. 4-9. ISSN: 2251-6832, 2012.

[3] G. T. Jeong, H. S. Yang, and D. H. Park, "Optimization of transesterification of animal fat ester using response surface methodology," Bioresources Technology, vol. 100, pp. 25-30, 2009.

[4] X. Fan, X. Wang, and F. Chen, "Biodiesel production from crude cottonseed oil: An optimization process using response surface methodology," The Open Fuel Energy. Sci. J., vol. 4, pp. 1-8, 2011.

[5] A. K. Tiwari, A. Kumar, and H. Raheman, "Biodiesel production from jatropha oil (Jatropha Curcas) with high free fatty acids: An optimized process," Biomass Bioenerg, vol. 31, pp. 569-575, 2007.

[6] E. Betiku, T. F. Adepoju, and B. O. Solomon, "Statistical approach to alcoholysis optimization of sorrel (Hibiscus Sabdariffa) seed oil to biodiesel and emission assessment of its blends lfe," Journal of Technology, vol. 2, pp. 20-24., 2012.

[7] T. F. Adepoju, J. O. Ojediran, and A. A. Okunola, "An optimization approach to oil extraction from chrysophyllum albidium and its quality characterization," International Journal of Innovative Research and Studies, vol. 2 , pp. 56-71, 2013a.

[8] T. F. Adepoju, J. O. Ojediran, A. A. Okunola, and C. Okolie, "Optimization of Benzyl Alcohol production via biotransformation of benzaldehyde using free cell of Saccharomyces cerevisiae in presence the $\beta$-Cyclodextrin," International Journal of Innovative Research and Studies vol. 4, pp. 1430-1444, $2013 \mathrm{~b}$.

[9] A. S. Achanta, J. G. Kowaski, and C. T. Rhodes, "Artificial neural network: Implication for pharmaceutical sciences," Drug Development and Industrial Pharmacy, vol. 21, pp. 119-155, 1995.

[10] J. Bourquin, H. Schmidli, P. Hoogevest, and H. Leuenberger, "Advantages of artificial neural networks (ANNs) as alternative modeling technique for data sets showing non-linear relationships using data from a galenical study on a solid dosage form," Eur. J. Pharm. Sci., vol. 7, pp. 5-16, 1998a.

[11] J. Bourquin, H. Schmidli, P. Hoogevest, and H. Leuenberger, "Pitfalls of artificial neural networks (ANNs) modeling technique for data sets containing outlier measurements using a study on mixture properties of a direct compressed dosage form," Eur. J. Pharm. Sci., vol. 7, pp. 17-28, 1998b.

[12] A. Sulaiman, A. M. Nikbakht, M. Khatamifar, M. Tabatabaei, and M. Ali Hassan, "Modeling anaerobic process for waste treatment: New trends and method-ologies. In: Dan, Y. (Eds). Biology, environment and chemistry," in Selected, Peer Reviewed Papers from the 2010 International Conference on Biology. Environment and Chemistry (ICBEC 2010), December 28-30, 2010 in Hong Kong. International Proceedings of Chemical, Biological and Environmental Engineering, 2011 , pp. 32-36.

[13] A. Ghaffari, H. Abdollahi, M. R. Khoshayand, and I. Soltani Bozchalooi, "Performance comparism of neural network training algorithms in modeling of biomodal drug delivery," International Journal of Pharmaceutics, vol. 327, pp. 126-138, 2006. 
[14] E. B. Gueguim Kana, J. K. Oloke, A. Lateef, and M. O. Adesiyan, "Modeling and optimization of biogas production on saw dust and other co-substrates using artificial neural network and genetic algorithm," Renew, Energy, vol. 46, pp. 276-281, 2012.

[15] M. Rajendra, P. Chandra Jena, and H. Raheman, "Prediction of pretreatment process parameters for biodiesel production," Fuel, vol. 88, pp. 868-875, 2009.

[16] A. Ebrahimpour, M. Basri, R. N. Z. R. A. Rahman, A. B. Salleh, E. Ryantin Gunawan, and M. Basyaruddin, "Comparison of estimation capabilities of response surface methodology (RSM) with artificial neural network (ANN) in lipase-catalyzed synthesis of palm-based wax ester," BMC Biotechnology, vol. 7, p. 53, 2007.

[17] T. F. Adepoju and O. Olawale, "Transesterification of CASO with low amount of free fatty acid and its optimization," Review of Energy Technologies and Policy Research, vol. 1, pp. 20-27, 2014.

[18] E. Betiku and O. A. Ajala, "Modeling and optimization of thevetiaperuviana (Yellow Oleander) oil biodiesel synthesisviamusa paradisiacal (Plantain) peelsas heterogeneous base catalyst: A case of artificial neural network and response surface methodology," Industrial Crops and Products, pp. 314-322, 2014.

[19] T. F. Adepoju, O. J. Ojediran, O. Olawale, and S. K. Layokun, "Application of response surface methodology (RSM) and artificial neural network (ANN) for achieving desire BA in the biotransformation of benzaldehyde using free cells of saccharomyces cerevisae and the effect of $\beta$-cyclodextrin," International Journal of Sustainable Energy and Environmental Research, vol. 3, pp. 62-79, 2014.

[20] K. M. Dasai, S. A. Survase, P. S. Saudagar, S. S. Lele, and R. S. Singhal, "Comparison of artificial neural network (ANN) and response surface methodology (RSM) in fermentation media optimization: Case study of fermentative production of scleroglucan," Biochem. Eng. J., vol. 41, pp. 266-278, 2008.

[21] G. Bosco Kana, J. K. Oloke, A. Lateef, and A. Oyebanji, "Comparative evaluation of artificial neural network coupled genetic algorithm and response surface methodology for modeling and optimization of citric acid production by aspergillus Niger MCBN297," Chemical Engineering Transaction, vol. 27, pp. 1974-9791, 2012.

[22] AOAC, Official methods of analyses of the association of official analytical chemists, 16th ed. Washington DC, USA: Association of Official Analytical Chemists, 1998.

[23] E. T. Akintayo and E. Bayer, "Characterization and possible uses of Plukenatiaconophora and Adenopusbreviflorus seed and seed oil," Bioresource Technology, vol. 85, pp. 95-97, 2002.

[24] A. Demirbas, "Fuel properties and calculation of higher heating values of vegetable oils," Fuel, vol. 7, pp. 1117$1120,1998$.

[25] X. Yuan, J. Liu, G. Zeng, J. Shi, J. Tong, and G. Huang, "Optimization of conversion of waste rapeseed oil with high FFA to biodiesel using response surface methodology," Renewable Energy, vol. 33, pp. 1678-1684, 2008.

Views and opinions expressed in this article are the views and opinions of the author(s), International Journal of Chemical and Process Engineering Research shall not be responsible or answerable for any loss, damage or liability etc. caused in relation to/arising out of the use of the content. 